\title{
The Relationships among Attitude towards Sports, Loneliness and Happiness in Adolescents
}

\author{
Cumaali Yavuz \\ Faculty of Sport Sciences, Firat University, Turkey
}

Copyright $\odot 2019$ by authors, all rights reserved. Authors agree that this article remains permanently open access under the terms of the Creative Commons Attribution License 4.0 International License

\begin{abstract}
The aim of the study is to investigate the relationship between the attitude towards sports, loneliness and happiness in adolescents. The study was conducted with a total of 403 high school students including 197 females and 206 males. For the data collection, the Oxford Happiness Questionnaire Short Form (OHQ-SF), the UCLA Loneliness Scale (ULS), the Attitude towards Sports Scale (ATSS) and personal information form were used. The analyses were conducted with the structural equation modeling (SEM). According to the findings of the study, a negative correlation was found between adolescents' attitudes towards sports and loneliness. The relationship between loneliness and happiness was also observed to be negative. As a result of the research, it was observed that adolescents' attitudes towards sports and loneliness were negatively related. In addition, loneliness was negatively correlated with happiness.
\end{abstract}

Keywords Sports, Loneliness, Happiness, Adolescents

\section{Introduction}

The period of adolescence is one of the most important periods in an individual's life. Adolescents usually go through this period with difficulties due to both the rules they need to obey in school and domestic conflicts in their families. Responsibilities of life encumbered on adolescents and the period of development they go through cause their problems to increase and life could become more complicated for them [1]. These circumstances sometimes force them to experience unwanted feelings more intensely. Considering this elevated pressure on individuals during the period of adolescence, it could be stated that they require various supportive mechanisms to cope with the problems they experience [2, 3]. In this period, it could be possible for them to cope with stress through various activities such as sports activities and cultural and artistic activities [4]. Initiation of a positive attitude towards sports in individuals could be an advantage for individuals. Engaging in sports activities could help adolescents improve their communication skills, adapt within teamwork and thus, socialize. Adolescents who carefully manage their time with sports also stand out among other adolescents with their athlete identity as healthy adolescents both physically and mentally and in social relationships. Today, it is highlighted that sports play a significant role in the socialization of individuals by enlarging their area of interests in order to meet their various expectations [5]. With the popular attitude towards sports in adolescents, acquisition of the terminal behaviors, such as assertiveness and teamwork, also increase. With sports activities, adolescents also improve themselves not only physically and mentally but also in terms of abilities of teamwork, self-discipline, chivalry, leadership, socialization and communication [6]. The reasons for most adolescents to engage in sports are not merely limited to movement and body. Elements such as the need for socializing with other individuals, fear of being alone and the need for being a social creature influence adolescents' attitude towards sports [7]. Sports constitute a significant tool of communication that creates potentials and opportunities for affiliations. It is stated that individuals who engage in sports gain new social environments and new friendships. Sports are seen as social behaviors that appeal both to the body and to the soul. Sports are effective in the adaptation of the individual to the society and in securing the physical and mental health of individuals [8]. As for loneliness, it is defined as "an unpleasant and subjective psychological situation that arises from the inconsistency between the present social relations of the individual and the desired social relations" (9. Considering all these studies, it could be stated that positive attitude towards sports could improve individuals' socialization and help individuals establish positive relationships with their environment. In the literature, it is emphasized that attitude towards sports is a significant factor that affects loneliness [10). The first hypothesis of this study was structured by considering the effects of attitude towards sports on loneliness. $\left(\mathrm{H}_{1}\right.$ : The attitude towards sports in adolescents is associated with loneliness significantly and 
negatively).

Weiss defined loneliness as the situation of unwanted individualization [11]. In previous studies, it was reported that individuals with higher levels of the feeling of loneliness felt unhappy more compared to those with lower levels of the feeling of loneliness [12,13]. Researchers also emphasized that happiness was possible for people by forming desired levels of interpersonal relations with other individuals $[14,15]$. In summary, researchers emphasize that loneliness is negatively associated with happiness. Individuals who think they are alone feel unhappy [16]. Happiness, especially together with the recent widespread of positive psychology, is one of the emphasized subjects $[15,17,18]$. In the literature, it is noted that loneliness is one of the most significant factors affecting happiness [19, $20,21]$. The second hypothesis of this study was structured by considering the effects of loneliness on happiness $\left(\mathrm{H}_{2}\right.$ : The loneliness in adolescents is associated with happiness significantly and negatively).

People are creatures that constantly interact with other individuals to maintain their existence. In fact, Maslow pointed out that the needs after satisfying basic survival needs such as eating and drinking and safety were the needs for love and respect and belonging while defining human needs. This is certainly possible when healthy relations are established with other individuals. Considering the period of adolescence, it is emphasized that the effects of the peer environment become more important than the effects of other individuals [1]. There are various methods for adolescents to be in communication and interaction with other individuals and one of these is by engaging in sports activities. Sports naturally involve activities that are to be conducted in interaction and in accord with other individuals. Thus, adolescents with positive attitudes towards sports are expected to participate in sports activities more and thus, to have lower levels of loneliness [10]. Researchers pointed out that students with lower levels of loneliness felt happier $[15,22,23]$. As a result, for adolescents, it is expected that loneliness decrease with increasing attitude towards sports and, with decreased loneliness, happiness is increased. The third hypothesis of this study was structured by considering the indirect effect of attitude towards sports on happiness $\left(\mathrm{H}_{3}\right.$ : The attitude towards sports in adolescents is indirectly, significantly and negatively related to happiness)

In the literature review, studies that investigated attitude towards sports, loneliness and happiness either in a singular or bilateral fashion were often encountered. However, it was observed that there was no study investigating the direct and indirect relationships between attitude towards sports, loneliness and happiness. When considered from this point of view, it is believed that this study will contribute to the literature. Additionally, considering the fact that there are few studies investigating the role of attitude towards sports in adolescents' loneliness and happiness, this study is deemed worthy of attention. Furthermore, it is believed that this study will inform future studies and researchers. In this period where technology addiction, virtual social relations and individualism have peaked especially among adolescents, engaging in sports activities could help adolescents eliminate the loneliness to which they are exposed and thus, experience a happy period of adolescence. Therefore, investigating the effects of attitude towards sports on the happiness of adolescents by adopting a structural model could contribute to the literature. It is believed that this study contributes to intervention programs for the effects of attitude towards sports on happiness and loneliness. The hypothetical model suggested in the study points out that adolescents' attitude towards sports is one of the factors that affect adolescents' happiness. According to the model, the attitude towards loneliness and sports in adolescents is negatively related. As a result, the hypotheses $(\mathrm{H})$ suggested in this study are as the following:

$\mathrm{H}_{1}$ : The attitude towards sports in adolescents is associated with loneliness significantly and negatively.

$\mathrm{H}_{2}$ : The loneliness in adolescents is associated with happiness significantly and negatively.

$\mathrm{H}_{3}$ : The attitude towards sports in adolescents is indirectly, significantly and negatively related to happiness.

\section{Method}

\subsection{The Research Model}

This study, which investigates the relationships between the levels of attitude towards sports, loneliness and happiness in adolescents, is a descriptive study. Before the initiation of the study, written permissions were obtained from the Ministry of National Education in Elazığ. While conducting the study, the informed consent form was read to participants in a classroom environment, and the study was initiated.

\subsection{The Study Group}

This study was conducted with 403 adolescents, 197 females (48.9\%) and 206 males (51.6\%). The participants were 14-18 years old. The majority of participants (163, $40.4 \%)$ were in $9^{\text {th }}$ grade while $100(24.8 \%)$ and 140 $(34.7 \%)$ were in the $10^{\text {th }}$ and $11^{\text {th }}$ grade, respectively.

\subsection{Data Collection Tools}

In this study, the Oxford Happiness Questionnaire Short Form (OHQ-SF), the UCLA Loneliness Scale (ULS), the Attitude towards Sports Scale (ATSS) and a personal information form were used as the data collection tools.

Oxford Happiness Questionnaire Short Form 
(OHQ-SF): The scale, which was developed by Hills and Argyle [24] in order to measure the happiness levels of individuals, and adapted into Turkish by Doğan and Çötok, consists of seven items [25]. The validity and reliability studies of the scale were conducted with university students. The measure has a 4-point rating scale. The possible obtainable points from the scale range from 7 to 42 and high scores indicate high level of happiness. The internal consistency coefficient of the scale, which consists of one sub-scale, is 0.74 and the test-retest reliability coefficient was determined to be 0.85 .

UCLA Loneliness Scale (ULS): The scale, which was developed by Hays and Di Matteo [26] and adapted into Turkish by Yildız and Duy [27], consists of seven items. The validity and reliability studies of the scale were conducted with adolescents. The measure has a 4-point rating scale. The possible obtainable points from the scale vary between 7 and 28. Low scores obtained from the scale indicate that the feeling of loneliness experience is low. As a result of exploratory factor analysis, it was determined that the scale consists of one sub-scale, which was further determined that this single sub-scaled structure has a fine suitability $(\chi 2=27.12, \mathrm{sd}=14, \chi 2 / \mathrm{sd}=1.94$, $\mathrm{RMSEA}=0.06$, RMR $=0.03, \quad$ SRMR $=0.04, \quad$ GFI $=0.97, \quad$ AGFI $=0.95$, $\mathrm{CFI}=0.98$, NFI $=0.96$, NNFI $=0.97$ ).

Attitude towards Sports Scale (ATSS): ATSS, which was developed by Şentürk [28] consists of 25 items and 3 sub-scales (giving importance to sports, be interested in sports and doing physical exercises or sports). ATSS is a 5 -point Likert type of scale (Completely Agree $=5$, Completely Disagree $=1$ ). The validity and reliability studies of the scale were conducted with adolescents. The possible obtainable points from the scale vary between 25 and 125 and high scores indicate high attitude towards sports. As a result of the confirmatory factor analysis, it was determined that the scale provided a fine suitability. The validity and reliability studies indicated that the scale was a suitable tool to measure attitude towards sports.

\subsection{Data Analysis}

Data were analyzed using AMOS and SPSS package software. Before conducting the analyses, multicollinearity, normality, outliers and sample size, which are prerequisites for structural models, were evaluated. Results showed that the skewness and kurtosis values were between acceptable values in social sciences (between -1 and +1 ), there were no outliers in the data set, correlation values did not cause a multicollinearity problem, VIF and tolerance values did not cause a multicollinearity problem and the sample size was large enough. Therefore, covariance and maximum likelihood methods were used to test the suggested hypothetical model. The suggested hypothetical model was investigated by using fit indices such as $\chi^{2} /$ sd, RMSEA, GFI, AGFI, CFI, IFI ve TLI (NNFI). The acceptable levels regarding the fit indices are presented in Table 1.
Table 1. Goodness of Fit Indices and Acceptable Limits

\begin{tabular}{ll}
\hline Indices & Acceptable Limits \\
\hline$\chi 2 /$ sd & $\leq 5$ Acceptable fit, $\leq 3$ perfect fit \\
\hline RMSEA & $\leq .10$ Weak fit, $\leq .08$ good fit,$\leq .05$ perfect fit \\
\hline GFI & $\geq .90$ good fit \\
\hline CFI & $\geq .90$ acceptable fit,$\geq .95$ good fit \\
\hline IFI & $\geq .90$ acceptable fit,$\geq .95$ good fit \\
\hline TLI (NNFI) & $\geq .90$ acceptable fit,$\geq .95$ good fit \\
\hline
\end{tabular}

(Cited by Savci \& Aysan) [29].

\section{Findings}

\subsection{Descriptive Statistics and Correlation Values}

The correlation values regarding the variables of attitude towards supports, loneliness and happiness are presented in Table 2.

Table 2. Correlations between the Latent Variables

\begin{tabular}{llll}
\hline & $\mathbf{1}$ & $\mathbf{2}$ & $\mathbf{3}$ \\
\hline 1- Attitude towards Sports Total Score & 1 & & \\
\hline 2- Loneliness & $-.168^{* *}$ & 1 \\
\hline 3- Happiness & $.299^{* *}$ & $-.368^{* *} 1$ \\
\hline
\end{tabular}

$* * \mathrm{p}<.01$

In the evaluation of the correlation values regarding latent variables in Table 1, it was determined that all of the pair correlations were statistically significant $(p<.001)$. It was observed that there was a negative correlation between the attitude towards sports total score and loneliness ( $\mathrm{r}=$ $-.17, \mathrm{p}<.01$ ), there was a positive correlation between the attitude towards sports total score and happiness $(r=.30$, $\mathrm{p}<.01$ ), which were at low levels and statistically significant. Between loneliness and happiness, moderate level and negative correlations at a significant level were observed $(\mathrm{r}=-.37, \mathrm{p}<.01)$.

\subsection{Results regarding the Suggested Hypothetical Model}

Considering the fact that the suggested hypothetical model meets the prerequisites of the structural model of the data (multicollinearity, multivariate normality, outliers and sample size), it was tested by using the maximum likelihood method. In the maximum likelihood method, the covariance matrix was utilized.

Results showed that the $\mathrm{t}$ value of the suggested hypothetical model varied between -4.155 and 24.684, and all of the paths were statistically significant at a .05 level. The fit indices for the hypothetical model were determined as $\chi 2 / \mathrm{df}=2.694$, RMSEA $=0.65 ; \mathrm{GFI}=0.92, \mathrm{AGFI}=0.89$, $\mathrm{CFI}=0.91, \mathrm{IFI}=0.91$. These findings indicated that the suggested hypothetical model had acceptable fit values. The analysis for the paths the hypothetical model was presented in Figure 1. 


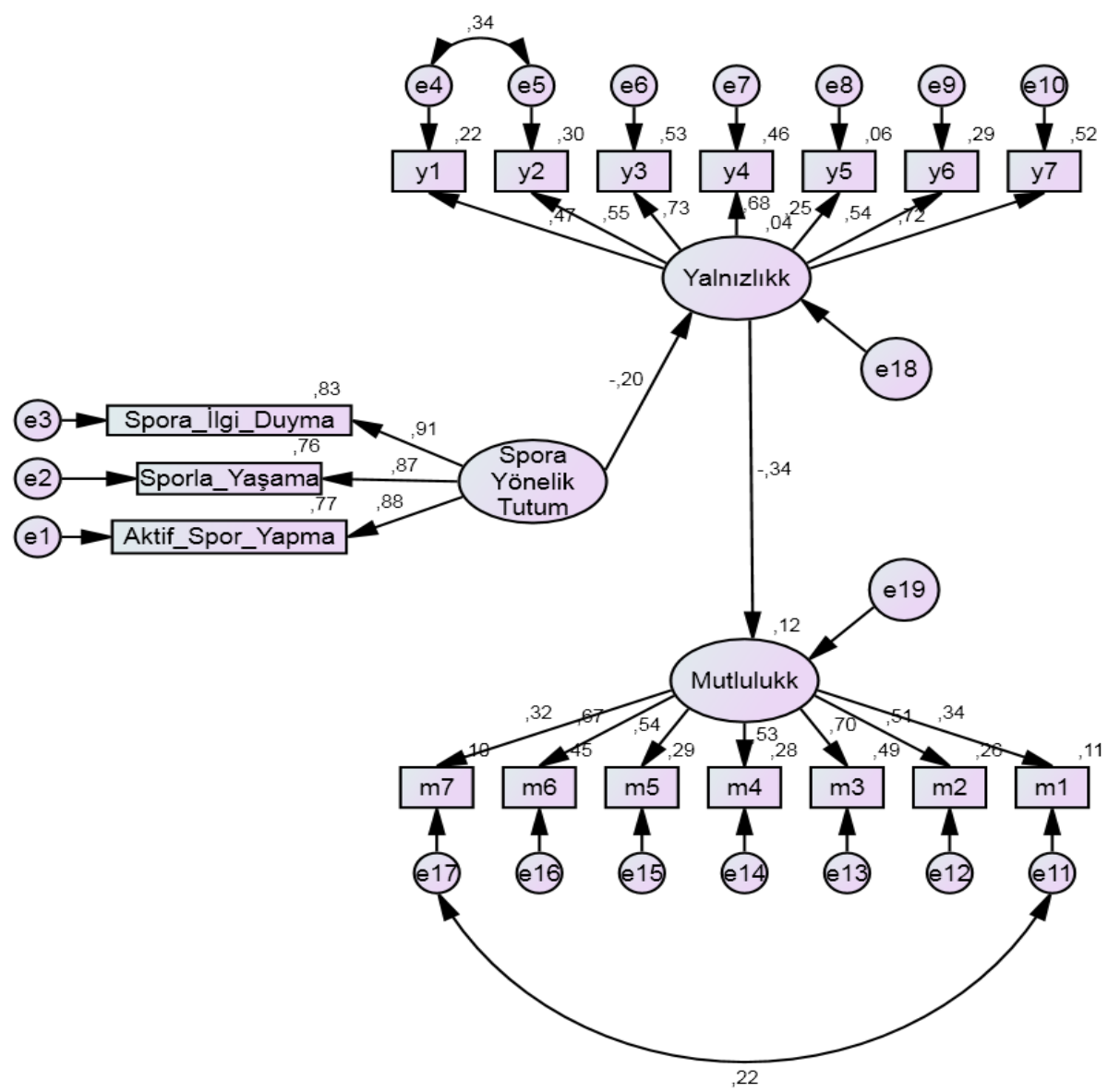

Figure 1. The paths diagram regarding the suggested hypothetical model

In the evaluation of the direct and indirect relationships regarding the suggested hypothetical model, the effect size was utilized. Accordingly, the values below .10 are regarded as low effects while those around .30 are regarded as moderate effects and those above .50 are regarded as high (wide) effects [30]. In the evaluation of the direct relationships regarding the variables of the suggested model, it was observed that between attitude towards sports and loneliness, the -.20 standardized path coefficient of attitude towards sports relationship to loneliness negatively and the magnitude of the effect between those variables was low. It was also observed that between loneliness and happiness, the -.34 standardized path coefficient of loneliness relationship to happiness negatively and the magnitude of the effect between those variables was moderate. Lastly, between attitude towards sports and happiness, the .10 standardized path coefficient of attitude towards sports relationship to happiness positively and the magnitude of the effect between those variables was low.

\section{Discussion, Conclusions and Suggestions}

In this study, the relationship between attitude towards sports, loneliness and happiness in adolescents was investigated by using structural equation modeling. As a result of the study, it was determined that the attitude towards sports in adolescents directly and negatively relationship to loneliness . However, loneliness directly and negatively relationship to happiness. Additionally, it was observed that attitude towards sports indirectly and positively relationship to happiness. As a whole, it could be stated that attitude towards sports in adolescents relationship to loneliness negatively and loneliness relationship to happiness negatively. It was also determined that attitude towards sports in adolescents relationship to happiness indirectly. In the evaluation of the model as a whole, it could be stated that the model, which investigates the relationships between the attitude towards sports, loneliness and happiness in adolescents, has an acceptable fit index values.

According to the first finding of the study, attitude towards sports in adolescents relationship to loneliness negatively. In other words, with the increasing positive attitude towards sports in adolescents, loneliness decreases. In the literature review, studies supporting this finding of the study were observed [31, 32]. In a study conducted with adolescents in Norway, it was reported that adolescents with higher participation in sports activities felt less lonely 
and experienced negative feelings less compared to other individuals [10]. This finding of the study could be explained via active social relationships, and respect and teamwork in interpersonal relationships. Firstly, most branches of sports require interaction with other individuals. Thus, it is expected of the adolescents with positive attitudes towards sports to be in social relationships more in order to participate actively in sports activities [33]. In this case, when individuals with more positive attitudes towards sports are compared with others, it is necessary for them to engage in social relations more. It could also be stated that adolescents with more social relationships with others are expected to have decreased loneliness.

Secondly, it is possible for adolescents with positive attitudes towards sports to participate regularly and actively in tournaments, matches and other sports activities only by being respectable in interpersonal relationships [34, 35]. In these types of activities, it is not possible for adolescents who are disrespectful to other individuals, violate rules and demonstrate other negative behaviors to participate regularly and actively in these activities. Thus, it is expected from the individuals with positive attitudes towards sports to develop relationships and to be respectful to other individuals. This situation also allows adolescents to have a wider social circle and to experience less loneliness.

Thirdly, individuals with positive attitudes towards sports are also expected to show more teamwork [34]. This is because the adolescents in Turkey generally prefer sports activities that require teamwork such as football, volleyball and basketball. For the individuals who wish to participate actively in this type of sports activities, it is necessary for them to engage in the spirit of teamwork in addition to sports abilities. It could also be stated that individuals with higher capacities for cooperation are attracted to more intense social relationships and experience loneliness less compared to other individuals.

According to the second finding of the study, loneliness in adolescents relationship to happiness negatively. In other words, with decreased loneliness, happiness increases. This is consistent with the literature [16, 20, 21]. This finding could be explained in the context of belonging, fellowship and insignificance. Firstly, individuals with positive attitudes towards sports join a group/team in which they feel belonged [37]. Adolescents who are active members of team sports or sports activity feel they are a part of that group, and this situation could decrease their feeling of loneliness. Secondly, individuals who actively participate in sports activities have opportunities to develop friendships and share their feelings with their friends. Additionally, taking an active part in a group and being needed in a team may allow adolescents to perceive themselves as valuable. All these positive factors could contribute to the happiness of adolescents.

According to the third findings of the study, attitude towards sports in adolescents indirectly and positively relationship to happiness. In other words, increased attitudes towards sports in adolescents indirectly increase their happiness. The result is consistent with the literature $[10,38]$ and can be explained in terms of loneliness, friendships, self-confidence, discipline and cooperation. Firstly, individuals with more positive attitudes towards sports are more likely to participate in sports activities, which allows them to be around peers [39] and develop or strengthen friendships, which may result in less loneliness. Thus, both the decrease in loneliness and the development of friendships could help individuals to feel good about themselves, to become happy [10], and to develop self-confidence [40] Furthermore, the individuals who put in the required into their sports develop discipline and teamwork, which can be generalized to academic work and career. In conclusion, in the proposed model, the attitudes towards sports in adolescents were negatively related to loneliness; loneliness was negatively associated with happiness. In this study, in other words, it appears that adolescents who do not engage in sports activities may be lonelier compared to those who engage in sports activities. Furthermore, in addition to being happier, adolescents who engage in sports activities seem to have no difficulties in developing friendships and forming social circles.

Based on the results of the study, it is possible to suggest future directions. Firstly, considering the positive benefits of positive attitudes towards sports for adolescents, it is deemed necessary to encourage adolescents to participate in sports activities. Secondly, in future studies, the effects of attitude towards sports on academic and other psychosocial variables could be investigated. Finally, the suggested hypothetical model could also be tested in other regions and with other age groups. In this study, convenience sampling method was used. In this research self-report type measurement tools are used. These should be considered as a limitation of the research.

\section{REFERENCES}

[1] Kiliç, M. (2013). Gerçek yaşam tadında: Gelişim dönemleri 2: Erinlik ergenlik. Ankara: Pegem Akademi.

[2] Steiner, H., \& Yalom, I. D. (2008). Ergen terapisi. İstanbul: Prestij Yayınları.

[3] Austin, V. L., Sciarra, D. T., \& Özekes, M. (2012). Çocuk ve ergenlerde duygusal ve davranışsal bozukluklar. Ankara: Nobel Yayın.

[4] Büyükyazı, G., Saracaloğlu, A. S., Karadeniz, G., Çamlıyer, H., \& Çamliyer, H. (2003). Sedanterler ile veteran atletlerin çeşitli değişkenlere göre atılganlık düzeylerinin karşılaştırılması. Gazi Beden Eğitimi ve Spor Bilimleri Dergisi, 8(4), 13-24.

[5] Göksel, A. G., Caz, Ç., Yazıcı, Ö. F., \& İkizler, H. C. (2017). 
Bölümlerdeki Öğrencilerin Spora Yönelik Tutumlarının Karşılaştırılması: Marmara Üniversitesi Örneği. Spor ve Performans Araştırmalar Dergisi, 8(2), 123-134.

[6] Centers for Disease Control and Prevention. (2000). Promoting Better Health for Young People Through Physical Activity and Sports. a Report to the President from the Secretary of Health and Human Services and the Secretary of Education. Fall 2000. CCC Healthy Youth.

[7] Baumann S. (1994). Uygulamalı spor psikolojisi. (Çev: C. İkizler, O.A. Özcan). İstanbul: Alfa Basım Yayım Dağıtım.

[8] Balcığlu İ. (2003). Sporun sosyolojisi ve psikolojisi. İstanbul: Bilge Yayınlart.

[9] Saraçoğlu Y. (2000). Lise öğrencilerinin yalnızlık düzeylerinin çeşitli değişkenlere göre incelenmesi. Yayınlanmamış Yüksek Lisans Tezi, Eğitim Bilimleri Enstitüsü, Samsun.

[10] Haugen, T., Säfvenbom, R., \& Ommundsen, Y. (2013). Sport participation and loneliness in adolescents: the mediating role of perceived social competence. Current psychology, 32(2), 203-216.

[11] Weiss, R. S. (1973). Loneliness: The experience of emotional and social isolation. Cambridge: The MIT Press.

[12] Booth, R., Bartlett, D., \& Bohnsack, J. (1992). An examination of the relationship between happiness, loneliness, and shyness in college students. Journal of College Student Development, 33(2), 157-162.

[13] Tuzgöl-Dost, M. (2007). Üniversite öğrencilerinin yaşam doyumunun bazı değişkenlere göre incelenmesi. Pamukkale Üniversitesi Ĕ̈itim Fakültesi Dergisi, 22(2), 132-142.

[14] Matthews, D. W. (1993). Relationship basics. North Carolina: North Carolina Cooperative Extension Service.

[15] Demir, Y., \& Kutlu, M. (2016). Üniversite öğrencilerinde sosyal etkileşim kaygısı ile mutluluk arasındaki ilişki: yalnızlığın aracı rolü. Gazi Üniversitesi Gazi Ĕ̆itim Fakültesi Dergisi, 36(1), 195-210.

[16] Hymel, S., Tarulli, D., Hayden Thomson, L., \& Terrell-Deutsch, B. (1999). Loneliness through the eyes of children. In K. J. Rotenberg \& S. Hymel (Eds.), Loneliness in childhood and adolescence (pp. 80-109). New York: Cambridge University Press.

[17] Kardaş, F., \& Yalçın, İ. (2018). Şükran: Ruh sağlığı alanında güncel bir kavram. Psikiyatride Guncel Yaklasimlar-Current Approaches in Psychiatry, 10(1), 1-18.

[18] Levine, M. (2000). The positive psychology of buddhism and yoga: Paths to a mature happiness. New York: Psychology Press.

[19] Cheng, H., \& Furnham, A. (2002). Personality, peer relations, and self-confidence as predictors of happiness and loneliness. Journal of Adolescence, 25(3), 327-339.

[20] Moore, D., \& Schultz, N. R. (1983). Loneliness at adolescence: Correlates, attributions, and coping. Journal of Youth and Adolescence, 12(2), 95-100.

[21] Heinrich, L. M., \& Gullone, E. (2006). The clinical significance of loneliness: a literature review. Clinical Psychology Review, 26, 695-718.
[22] Saxena, S., Van-Ommeren, M., Tang, K. C., \& Armstrong, T. P. (2005). Mental health benefits of physical activity. Journal of Mental Health, 14(5), 445-451.

[23] Tomson, L. M., Pangrazi, R. P., Friedman, G., \& Hutchinson, N. (2003). Childhood depressive symptoms, physical activity and health related fitness. Journal of Sport \& Exercise Psychology, 25, 419-439.

[24] Hills, P., \& Argyle, M. (2002). The oxford happiness questionnaire: a compact scale for the measurement of psychological well-being. Personality and Individual Differences, 33(7), 1073-1082.

[25] Doğan, T., \& Çötok, N. A. (2016). Oxford mutluluk ölçeği kısa formunun Türkçe uyarlaması: Geçerlik ve güvenirlik çalışması. Türk Psikolojik Danışma ve Rehberlik Dergisi, 4(36), 165-170.

[26] Hays, R. D., \& DiMatteo, M. R. (1987). A short-form measure of loneliness. Journal of Personality Assessment, 51(1), 69-81.

[27] Yildiz, M. A., \& Duy, B. (2014). Adaptation of the short-form of the UCLA loneliness scale (ULS-8) to Turkish for the adolescents. Dusunen Adam, 27(3), 194-203.

[28] Şentürk, H. E. (2012). Spora yönelik tutum ölçeği: Geliştirilmesi, geçerliliği ve güvenirliği. $C B \ddot{U}$ Beden Ĕgitimi ve Spor Bilimleri Dergisi, 7(2), 8-18.

[29] Savci, M., \& Aysan, F. (2016). Relationship between impulsivity, social media usage and loneliness. Educational Process: International Journal, 5(2), 106-115. doi.org/10.12973/edupij.2016.52.2.

[30] Kline, R. B. (2005). Principles and practice of structural equation modeling. USA: Guilford Press.

[31] Taliaferro, L. A., Rienzo, B. A., Miller, M. D., Pigg, R. M., \& Dodd, V. J. (2010). Potential mediating pathways through which sports participation relates to reduced risk of suicidal ideation. Research Quarterly for Exercise and Sport, 81(3), 328-339.

[32] Poulsen, A. A., Ziviani, J. M., Cuskelly, M., \& Smith, R. (2007). Boys with developmental coordination disorder: Loneliness and team sports participation. American Journal of Occupational Therapy, 61(4), 451-462.

[33] Gantz, W. (2013). Reflections on communication and sport: On fanship and social relationships. Communication \& Sport, 1(1-2), 176-187.

[34] Duquin, M. B., \& Schroeder-Braun, K. (1996). Power, empathy, and moral conflict in sport. Peace and Conflict, 2(4), 351-367.

[35] Stanger, N., Kavussanu, M., \& Ring, C. (2017). Gender moderates the relationship between empathy and aggressiveness in sport: The mediating role of anger. Journal of Applied Sport Psychology, 29(1), 44-58.

[36] Duda, J. L. (1989). Relationship between task and ego orientation and the perceived purpose of sport among high school athletes. Journal of Sport and Exercise Psychology, 11(3), 318-335.

[37] Walseth, K. (2006). Sport and belonging. International Review for the Sociology of Sport, 41(3-4), 447-464. 
[38] Donaldson, S. J., \& Ronan, K. R. (2006). The effects of sports participation on Young adolescents'emotional well-being. Adolescence, 41(162).

[39] Timperio, A. F., van-Stralen, M. M., Brug, J., Bere, E., Chinapaw, M. J., De Bourdeaudhuij, I., ... \& Salmon, J. (2013). Direct and indirect associations between the family physical activity environment and sports participation among 10-12 year-old European children: testing the EnRG framework in the ENERGY project. International Journal of Behavioral Nutrition and Physical Activity, 10(1), 15.

[40] Vealey, R. S., \& Campbell, J. L. (1988). Achievement goals of adolescent figure skaters: Impact on self-confidence, anxiety, and performance. Journal of Adolescent Research, 3(2), 227-243. 